\title{
Nuevas tendencias sociales en Las bicicletas son para el verano, de Fernando Fernán Gómez
}

\author{
Dr. Abdel Hamid Aly Aly Ghalab \\ Departamento de Español - Facultad de Al-Alsun \\ Universidad de Kafrelsheikh
}

\section{Introducción}

Desde su nacimiento en la Grecia Clásica, el teatro ha sido un espacio de nuevas ideas, símbolos, representaciones y discursos. Los elementos que componen dicho espacio reflejan y marcan las inquietudes generadas por los cambios sociales, pretendiendo proporcionar respuestas propias a los problemas y conflictos del ser humano. Cuando las sociedades pasan de un extremo a otro a causa del desarrollo normal de los seres vivos y el paso del tiempo o por cambios radicales motivados por revoluciones o guerras. Se manifiestan inmediatamente las nuevas tendencias y los conceptos ponen su sello en las sociedades, en el teatro y en los demás géneros literarios. Las consecuencias de la tragedia de la Guerra Civil en España han sido fuente de inspiración para muchos escritores. A partir de los años cincuenta hasta finales del siglo pasado, se producía teatro planteando las amarguras, las frustraciones y los sufrimientos de aquella desafortunada época de enfrentamientos. En la posguerra se produjeron cantidad de obras que tratan la temática de sus secuelas, pero éstas fueron mutiladas por la censura después de la victoria de Franco. La mayoría de las obras y escritores relacionados con los efectos e impactos de la Guerra Civil ha sido estudiada, por lo que escribieron estos dramaturgos en el exilio o bien por el reflejo de la España

1 de posguerra de los que se quedaron dentro.

El tratamiento del tema de la Guerra Civil durante la dictadura de Franco era un tabú. Sólo podía representarse desde la perspectiva política e ideológica que justificase la sublevación militar contra el gobierno legítimo del Frente Popular, que ganó las elecciones democráticas en febrero de 1936. Algunos dramaturgos plantearon este tema desde una postura basada en la ética cristiana como Joaquín Calvo Sotelo, en La muralla (1954). Su conflicto dramático abarca la conciencia moral del protagonista, que para salvar su alma antes de la muerte, siente necesidad de devolver sus bienes adquiridos ilegalmente durante la guerra. En El tragaluz (1967), de Antonio Buero Vallejo, se puede contemplar la destrucción de una familia por las circunstancias históricas extremas. También, en 1967, Antonio Gala estrena Noviembre y un poco de yerba, que resalta las consecuencias destructivas. Pero los dramaturgos del exilio pudieron representar el tema de esta confrontación de todo un país, con gran libertad de opiniones. Rafael Alberti escribió, en 1956, Noche de guerra en el Museo del Prado, que no pudo estrenarse en España hasta 1978, después de la muerte de Franco. 


\section{Dr. Abdel Hamid Aly Aly Ghalab}

Durante los años de la transición democrática se incrementan las libertades paulatinamente y desaparece la censura. Por eso, se da la posibilidad de plantear abiertamente el tema que nos ocupa, por parte de Fernando Fernán Gómez en Las bicicletas son para el verano. Esta pieza es considerada uno de los grandes éxitos teatrales de los años ochenta. Con la llegada de la democracia y mirando hacia atrás, los dramaturgos empiezan a trazar y diseñar textos y montajes para curar las heridas del pasado, obras de reconciliación, como La Cena de los generales (1982), de José Luis Alonso de Santos.

Por muchas razones Las bicicletas son para el verano es una pieza literaria muy particular, ya que ofrece un retrato de la vida cotidiana de los madrileños durante la contienda a través de la historia de una familia española. Puesto que todas las unidades de la acción dramática que forman la progresión de la acción principal están vinculadas tanto con el exterior como con el interior, lo que ocurre en el exterior, afecta a los conflictos personales de los personajes que aparecen encima del escenario. El espacio interno, que es el ambiente doméstico, siempre se superpone al externo. Además, existe un contraste entre Historia e Intrahistoria. Esta oposición se traslada simbólicamente a la escena por medio de efectos acústicos que sirven de vínculo entre el espacio exterior -espacio de la Historia- y el ámbito doméstico. El lector o el espectador de esta obra percibe la tragedia colectiva del pueblo español, en un espacio geográfico muy reducido. En este pequeño lugar se reproducen casi todos los conflictos y enfrentamientos de ambos bandos durante la lucha armada.

Como se ha estudiado esta obra desde distintas perspectivas, nuestro objetivo en este trabajo es resaltar y subrayar los conceptos y aspectos literarios que nacieron durante la Guerra civil española, con el fin de cambiar de vida y todas aquellas restricciones. La libertad del individuo por encima de cualquier autoridad ha sido una de las nuevas tendencias que impulsaron los republicanos para ganar terreno durante la cruenta guerra. La cuestión de matrimonio, las madres solteras, la ideología anarquista sobre el amor libre, el divorcio, el trabajo sin fronteras, sin propiedades y sin desigualdades, todos estos elementos o anhelos reunidos fueron la utopía de la sociedad que deseaba la mayoría de los españoles en aquel entonces. Dichas tendencias se manifiestan de maneras diversas para arrojar luz sobre la visión de la sociedad hacia la conducta del ser humano y el modo de enjuiciar los actos de los demás. Fernán Gómez pudo representarlo, con éxito clamoroso, a través de sus personajes en esta comedia de costumbres ${ }^{2}$, según la calificación de su autor, los detalles sencillos de la vida de los españoles. Esta obra teatral fue bien recibida tanto por los críticos como por el público. El elogio de la crítica fue unánime por el carácter memorial de esta pieza. Por tanto, a continuación dedicaré un pequeño 
apunte para la crítica y el estreno de la obra, antes de adentrarnos en el abordaje de nuestro trabajo.

\section{Crítica y estreno}

No debemos pasar por alto las opiniones de los críticos y las resonancias magníficas e irrepetibles del estreno. Puesto que, el alto nivel literario y artístico, y la importancia de esta obra en el contexto del teatro español del siglo XX, se concibió a partir del éxito espectacular y triunfal que la acompañó desde los primeros momentos de su estreno en el Teatro Español de Madrid, el 24 de abril de $1982^{3}$. La crítica elogia la obra, ya que la recibió y la aplaudió como pieza magistral. Eduardo Haro Tecglen opina que:

Fernando Fernán Gómez ha escrito una obra maestra: Las Bicicletas son para el verano. Probablemente su virtud con respecto a otros autores -nuevos o antiguos, grandes o pequeños- de este tipo revuelto es no haberse dejado acongojar por tantas cosas como pesan hoy sobre los escritores de textos teatrales; no haber retrocedido ante una narración, ante un tema de guerra civil, y un reparto largo, y una necesidad de decorados ${ }^{4}$.

Fernán Gómez es una figura central de las artes escénicas de España. Su ingenio y sabiduría, su larga trayectoria en el ámbito del teatro como actor, como director y autor, le hacen reproducir, de alguna forma, la dialéctica entre la verdad literaria y la verdad histórica que proyecta Aristóteles en su Poética. Cada personaje, en Las bicicletas son parar el verano, aporta una especial particularidad al progreso de la acción dramática. A lo largo de los segmentos de esta obra podríamos deducir que el autor mantiene una postura crítica con los dos bandos de esta guerra, sin saber de qué parte se inclina. Sobre el brillante estreno, que tuvo grandes ecos en aquel momento, Fernando Bejarano dice:

Durante varios minutos, el público que abarrotaba el Teatro Español, puesto en pie, brindó una de las ovaciones más calorosas que en las recientes temporadas se han dedicado al estreno de un autor español. Fernando Fernán Gómez, sensiblemente emocionado, quiso corresponder con un saludo: "Quisiera pedir que se suprimiese esta costumbre de tener que hablar el autor, porque en estos momentos apenas acierto a deciros gracias". Y remarcó su agradecimiento señalando a toda la compañia 5 .

El carácter autobiográfico de esta pieza, ganadora del premio Lope de Vega en 1977, nos hace ver la evolución de un muchacho desde su adolescencia hasta la madurez. Durante esta evolución, se observan sus inclinaciones y sus problemas, las de un chico de su edad, sus inquietudes culturales relacionadas con la literatura y el cine, sus charlas con los amigos, sus deseos sexuales, sus planes para el futuro, que serán distintos a lo que imagina. Pero la visión supuestamente ingenua de Fernán Gómez, le hace 


\section{Dr. Abdel Hamid Aly Aly Ghalab}

concebir la guerra, en esta obra teatral, como un juego de imposible tránsito a la realidad inmediata centrada en unos planes de vacaciones del verano. Porque la guerra para el autor era un motivo secundario en esta pieza, ya que las ilusiones, los sentimientos y las decepciones de los personajes que representan un grupo familiar, que sufre las consecuencias de este enfrentamiento civil, es el eje principal que mueve a los personajes. También lo que se teatraliza en esta obra no es la guerra en sí, sino los efectos acústicos y atronadores de la misma. Por eso, Javier Gutiérrez Palacio opina que Las bicicletas son para el verano es una obra muy diferente a otras que tratan la Guerra Civil:

Lo que diferencia esta obra de otras ambientadas también en la contienda fratricida es su ausencia de enfrentamiento; no es una obra maniquea, ni de combate; no hay un deseo de abrir heridas (aunque esto no significa que no haya ideología en la obra, que la hay, $y$ además el autor no oculta sus simpatías politicas). El autor ha querido hacer una crónica intrahistórica, pero comprometida ideológicamente ${ }^{6}$.

Algunos críticos encuentran como antecedentes de la obra de Fernán Gómez, la de La calle ${ }^{7}$, del dramaturgo americano Elmer Rice. Es una pieza en tres actos que plantea, mediante un espacio determinado, las esperanzas hacia la libertad y la independencia de la mujer, el amor libre, las inquietudes de los jóvenes y los nuevos conceptos que impregnaron la sociedad de Estados Unidos en aquel entonces. El escenario se ubica en el edificio de vecinos, con alguna breve salida al exterior: "Podría decirse que se encuentran en esta corte de diablo cojuelo vidas sencillas, vidas cotidianas, de no haber entre ellas un personaje extraordinario, una auténtica creación humana como el que interpreta Agustín González con una solvencia y una calidad de gran actor"8.

También, no debemos olvidar en este apartado, lo que escribió Ángel Berenguer en su libro Tendencias del teatro español durante la transición politica (1975-1982), donde describe el estreno con admirable rigor y atribuye el tratamiento de la obra a la línea instaurada en España por Buero Vallejo. "Las bicicletas son para el verano se convierte en una de las obras con mayor éxito y aceptación en los años 80. La pieza recrea, evocándola en tonos alternativos de drama y comedia, la vida cotidiana de una familia en el Madrid de la Guerra Civil, a través de un tratamiento que, en la línea instaurada en España por Buero, trasciende el particularismo de los personajes para dar una impresión del entorno que los rodea"".

La larga trayectoria de Fernando Fernán Gómez está llena de prestigiosos premios, galardones y condecoraciones como el Premio Nacional de Teatro en 1985, el Premio Nacional de Cinematografía en 1989 o el Premio Príncipe de Asturias de las Artes en 1995. En el 2000 recibió el Oso de Honor en el Festival Internacional de Cine de Berlín a toda su trayectoria, y en el 
2001, la Medalla de Oro de la Academia de las Artes y las Ciencias Cinematográficas de España.

\section{Cambiar de vida y cambiar la vida}

El verbo 'cambiar' hace referencia a dejar una cosa o situación para tomar otra. El objetivo primordial del teatro social es la práctica para la trasformación social, no es sólo una reflexión sobre ella. También es un subgénero teatral en el que un grupo explotado y oprimido por determinados poderes se levanta contra la injusticia de la tiranía. Algunas opiniones consideran que toda la producción teatral es social. Partiendo de que el teatro es un recurso que nos permite articular propuestas de expresión con lenguajes muy diversos ${ }^{10}$. Nuestra intención es alejarnos de esta polémica y centrarnos en el concepto de 'cambio', como presenta y representa Fernando Fernán Gómez en su obra centrada en los años del conflicto, y en cómo actúan los personajes, que no están oprimidos ni explotados en apariencia, y no luchan por determinadas conquistas de clase dentro de un contexto social.

Aunque Las bicicletas son para el verano termina por donde empieza, en el mismo espacio, el grupo de los personajes vencidos recogen el sentido de estas aspiraciones, anhelos y esperanzas, a lo largo de esta pieza. Sus deseos de cambiar la vida están presentes en los diálogos y en la mayoría de las intervenciones de aquellos personajes. Las obsesiones de cambio les convertía en seres que confían en un mundo imaginario más que en la realidad impuesta por los nacionales. Al comenzar la obra, se observa que las ideologías de los personajes no están definidas ni concretadas claramente. Pero, poco a poco, se introducen en un nuevo camino que parece abrirse ante ellos. En la segunda parte de esta pieza, en el cuadro IX, con la aparición del joven miliciano, Anselmo, de la parte republicana, luciendo sus pistolas y el pañuelo al cuello, y con los colores anarquistas, se sintetizan todas las esperanzas ácratas y libertarias que reflejan los partidarios de aquella parte. La acción dramática tiene lugar en el comedor de doña Dolores, donde se inicia el diálogo con el joven, comentando el crecimiento de Luís, que lleva casi dos años sin verle. Anselmo viene de Valencia, la sede del Gobierno republicano después de su traslado desde Madrid. Mientras habla, los demás personajes atentos y centrados en sus intervenciones y diálogos, se oyen los disparos de fusiles que suenan de vez en cuando. Doña Dolores, como los demás miembros de su familia, está agobiada y dolorida, y sufre por los combates y los bombardeos. Por eso, la llegada de Anselmo disminuye la tensión dramática y los conflictos personales que giran en torno al fin de la guerra:

Doña Dolores: -Pero estarás enterado de más cosas que nosotros. Porque aquí oímos la radio, sí, y nos llegan bulos y más bulos todos los días, pero no se puede una fiar. Algunas veces hemos oído la radio del otro lado...

Anselmo: -Bah, una sarta de mentiras. Propaganda. 
Doña Dolores: -Ya, por eso digo, tú, ¿cuándo crees que acabará esto? Anselmo: -En seguida. ¿No ves cómo les hemos sacudido aquí? En la Universitaria, en la Casa de Campo, en todo el frente. Hemos ganado la batalla. Les hemos parado ${ }^{11}$.

Con las respuestas del miliciano se incrementa paulatinamente la tranquilidad y la calma, puesto que sus sugerencias y promesas sobre el futuro sonriente que esperan los españoles, en todas las esferas de la vida, están por venir. Esperan que la paz y las libertades impregnarán la sociedad y no habrá explotadores ni explotados. Los españoles disfrutarán de las riquezas que van a crear y la sociedad española será una sociedad internacional. Cada uno hará lo que le apetezca y los trabajadores organizarán la distribución de los frutos del trabajo. A pesar de los bombardeos y disparos que se suenan desde fuera del escenario, este tipo de diálogo por parte de Anselmo baja la energía dramática y desaparece la tensión. Como la familia de don Luis, desea que la guerra llegue a su fin, gane quien gane. La intervención de este chico, manipulado por fuerzas contrarias al bando nacional, atrae profundamente al grupo de los jóvenes: Manolita, Luis y su amigo Pedro.

En el cuadro XI, la acción dramática tiene lugar en el comedor de Doña Dolores, sentada con su hija Manolita. Ésta se presenta, desde el inicio de la obra, como una chica corriente, que ha decidido ser actriz, en una sociedad que desestima esta profesión para el género femenino. Su vida ha experimentado un cambio radical desde su embarazo, por el miliciano. Mientras se abre el telón, vemos a la madre espantada tras enterarse de la noticia de dicho embarazo y sin saber qué hacer. Normalmente, el comienzo de cualquier unidad de acción dramática, es como una especie de prólogo de las acciones actorales que veremos posteriormente, pero este acto comienza por un punto culminante, puesto que la noticia hace que la madre 'se lleve las manos a la boca'. El diálogo entre ambos personajes sigue con un nivel de energía dramática muy elevado, motivado por la indiferencia de Manolita. Doña Dolores expresa su inquietud atribuyendo este escándalo a la guerra: “¡Esta guerra, esta maldita guerra!" Y la chica niega los argumentos de su madre: "Una cosa así me podía haber ocurrido aunque no hubiera guerra" ${ }^{2}$. Sus intervenciones nos hacen recordar el diálogo del personaje de Andrés, el cocinero, en La cena de los generales, de José Luis Alonso de Santos, con Miguel, La Chef y el Maître, que en un momento determinado se desahoga, anunciando sus amarguras por los cambios causados con motivo de la Guerra Civil:

Tenía que haber visto usted esta cocina en otro tiempo, no en guerra, antes de que se sublevaran los generales. Haciamos fiestas, todos juntos, cocineros y camareros. Cumpleaños, bautizos... El más 
alegre de todos era Alfredo. El chef... Creímos que el mundo iba a cambiar, y ha cambiado, a peor ${ }^{13}$.

Son dos visiones paralelas en contextos muy diferentes a nivel pragmático. La primera, castiga el embarazo ilícito de la hija, durante los años del conflicto y, en la segunda, Andrés atribuye el cambio socio-político de posguerra a la contienda bélica.

Mientras sigue el diálogo entre madre e hija con un tono trágico sobre la relación que tuvo Manolita, y sus secuelas dramáticas, suena el timbre de la puerta y se oye un ruido enorme cuando aparece doña Antonia. Ésta es claramente de derechas y una mujer tradicional de pensamiento y modo de juzgar los comportamientos de los demás. Para ella, los republicanos son 'golfos'. También sufre, como sus dos hijos: hambre, miedo y frío. Con la aparición de este personaje se presagia que algo malo ha sucedido, porque entra angustiada y se queda cortada al ver a Manolita. Doña Antonia viene para desahogarse ya que tiene la necesidad de hablar con alguien. Sus lágrimas y su llanto suben la tensión dramática otra vez y doña Dolores no puede dominar la situación. Poco a poco ésta ha podido contenerla para que explique los argumentos de ese pánico y horror. Doña Antonia descubre, a través del mensaje de un desconocido, que Rosa, la novia de su hijo Pedro, es prostituta. Sabiendo que es 'una mujer de la calle', Pedro la quiere mucho y no está dispuesto a que se vaya de casa. 'Ella también le quiere'14. A parte de su conflicto psíquico y espiritual, doña Antonia no imagina cómo vivir con Rosa bajo el mismo techo. La pobre doña Dolores se cansa y se rinde ante los choques y cambios absurdos, existenciales, ideológicos y trascendentales, ya que antes de la llegada de su vecina recibió un enorme choque, representado por el embarazo de cuatro meses de su hija, y no sabe cómo va a ser su futuro en situaciones económicas muy críticas. $\mathrm{Y}$ ahora intenta calmar a su compañera, confesándole que realmente el mundo ha cambiado y que la generación joven tiene nuevas tendencias y criterios, que de ninguna manera pertenecen y corresponden a la generación de los padres. Doña Dolores lo sintetiza manifestando su conformismo y sumisión ante un contexto cambiante, de forma razonada:

Doña Dolores: -Doña Antonia... Ahora las cosas están cambiando... Algunas han cambiado del todo... Y hay problemas que antes parecían muy gordos y ahora ya no son nada... Fijese usted, lo que hacía esta chica, Rosa, por ejemplo, dentro de nada, cuando este acabe, ya nadie lo hará. Y entonces, ¿quién se va a acordar de que ella lo hacía? Y aunque se acuerden, ¿a quién le va importar? Éste ya no es nuestro mundo, doña Antonia. Y el mundo que va a venir, mucho menos ${ }^{15}$.

La presencia de víctimas, muertes y desapariciones, que abundan en la segunda parte de esta obra, desde el inicio hasta el final, generan cambios 


\section{Dr. Abdel Hamid Aly Aly Ghalab}

trascendentales. Este tema aparece más de una vez en la obra de Fernando Fernán Gómez. Por ejemplo: muerte de José Fernando, un capitán miliciano y padre del hijo de Manolita, que ha sido asesinado en la sierra; o el fallecimiento de Juan, hijo de doña Antonia, y segundo esposo de esta chica, después de la muerte José Fernando, el miliciano. Sus dos hombres han caído víctimas de la guerra, uno tras otro. Ella, ahora, es una mujer viuda con un niño pequeño. Los dos personajes invisibles, Heliodoro y Catalina, que murieron en el bombardeo del barrio de Argüelles, y la hija a la que han evacuado a Alicante. Antonio, el nieto de la tía Eudosia, que murió y no se sabe cuál de los bandos le ha fusilado. Doña Dolores resume toda esta tragedia en una frase: "No pasa un día sin que nos llegue la noticia de una muerte"16. La interpolación acústica es un elemento de suma importancia y es un factor integrante, puesto que los bombardeos, los disparos y los sonidos estridentes representan, dentro del hecho escénico, un componente muy interesante, y su función es elevar la energía dramática, presagio de hechos trágicos que pueden suceder. Además, ayudan al público a entender las intenciones y sentimientos del autor en la creación de los personajes y de la acción dramática. La buena memoria y la sensibilidad de Fernán Gómez fueron los resortes para manifestar fielmente la trama de este tema en el teatro. De tal forma, éste demuestra lo que comenta Antonin Artaud en su libro El teatro y su doble, donde explica: "El teatro debe darnos todo cuanto pueda encontrarse en el amor, en el crimen, en la guerra o la locura, si quiere recobrar su necesidad"17. Algunas de las tragedias griegas que produjeron los clásicos estaban basadas en episodios que parten de guerras. La historia del teatro griego está llena de ejemplos. La guerra trae siempre consigo fatales consecuencias, tal y como sucedió en la Guerra Civil española, y no solamente en ésta, sino cualquier otra guerra, como el reciente desastre de la guerra de Iraq, Yemen, Siria y Libia. Pero, la representación particular que nos presenta Fernán Gómez sobre la guerra es distinta e impresionante. Porque, a pesar de las diferencias ideológicas y políticas de los personajes, ellos no se enfrentan: dialogan, aceptan, se ayudan y se desahogan unos con otros. También, no existen actos violentos a causa de sus inclinaciones y simpatías.

Más tarde, ya en 1939, aparecen muchos cambios en la vida de todos los personajes, algunos para mejor, los vencedores, como Maluli, que viajará a Suiza para acabar sus estudios; y Pablo, que viajará a Barcelona con su familia para conseguir el puesto de trabajo nuevo de su padre. Otros para peor, los vencidos, como María, que se separa de su paisano Basilio; y Pedro, que se queda en el campo de concentración dejando a su madre y a Rosa solas. Cuando termina la guerra, don Luis y su hijo pasean por la Ciudad Universitaria, por las ruinas que quedan de ella. El padre le comenta que probablemente lo detendrán y lo apresarán, y que él, Luis, debería ser el nuevo hombre de la familia y tendrá que protegerla. La obra termina con la famosa 
frase de don Luis: "Sabe Dios cuándo habrá orto verano"18. Esta frase inspira la sensación de fracaso, impotencia y resignación ante la evidencia de una derrota y un largo invierno en la vida de los españoles.

\section{Matrimonios y divorcios}

La mujer es una de las grandes columnas vertebrales en Las bicicletas son para el verano, un eje importante en esta pieza. Por motivos históricos, ella siempre ha sido víctima de los actos violentos del hombre y de las circunstancias sociales. Poco a poco, la mujer va adquiriendo conciencia de su personalidad y acaba separándose de los conceptos sociales anticuados de la moralidad vigente en las épocas anteriores. Esta toma de conciencia de la mujer es destacada en su puesto activo dentro de la sociedad. Su significación social y su importancia evolucionan a lo largo de esta obra. Fernán Gómez diseña los personajes femeninos en dos bloques: El primero, se enmarca en la generación de las madres, excepto doña Marcela, que vive y convive con conceptos antiguos y tradicionales; y el segundo, la generación de las jóvenes, que sienten que no pueden ser un juguete o una muñeca en manos de un hombre. Creemos que, con este planteamiento, el autor presenta la idea de las dos Españas: la España tradicional y fanática, por un lado, y la liberal y progresista, por otro. Así, él subraya una crítica de la sociedad dividida y condicionada por la contradictoria realidad española de la época.

Si tomamos como ejemplo la primera relación que mantuvo Manolita con el miliciano, mostrando un nuevo concepto del matrimonio y las relaciones de pareja, descubrimos la diferencia generacional de pensamiento entre hijos y padres. Desde el punto de vista de Manolita, el mutuo acuerdo entre la pareja es lo fundamental. Por eso, se defiende ante doña Dolores utilizando argumentos racionales: "Nos queríamos mucho, mamá. No soy ninguna mujer engañada. No nos habríamos casado, porque ninguno de los dos creíamos en eso... Pero habríamos vivido juntos hasta que nuestro amor se hubiese acabado"19. La satisfacción personal y el convencimiento de Manolita en el cuadro XI, se manifiestan en estos parlamentos con la madre. Su visión es muy liberal, razonable y feminista. Sin embargo, las opiniones de doña Dolores, la madre, expresan una profunda angustia y el miedo por la visión catastrofista del mundo que rodea a su hija en particular y a la familia de don Luis en general. Normalmente, los choques generacionales, en la literatura y en la vida real, engendran violencia y horror. Pero Fernando Fernán Gómez presenta esta idea con su máximo nivel artístico y racional. Esta misma idea es resaltada en La condecoración, de Lauro Olmo, en su máxima figura trágica. En ella, la divergencia entre hijos y padres se convierte en absoluta enemistad y en profundo rechazo por ambas partes. La indiferencia que caracteriza a don José en su trato con Pedro, su hijo, provoca fatales consecuencias en éste y en los demás personajes que componen la célula familiar. Los hechos trágicos principales provocan otros hechos penosos también, aunque secundarios, 


\section{Dr. Abdel Hamid Aly Aly Ghalab}

dentro de la obra. Aparte de lo que acabamos de mencionar sobre las ideologías, pensamiento y tradiciones, Olmo siempre ve a la mujer como víctima: "Por lo general, cuando cojo a la mujer española, pues la veo como víctima de unos prejuicios, de una estructuración social determinada. Siempre he visto a la mujer como gran víctima" ${ }^{20}$. Fernán Gómez tiene la misma postura, pero presenta a la mujer bajo un molde diferente: Una mujer que dialoga y convive con los sucesos de su época, una mujer independiente y responsable de sus hechos y de sus actos.

Después de la muerte del miliciano, Manolita tiene un hijo fruto de esta relación. Éste no constituye ningún impedimento para que Julio, hijo de doña Antonia, le vuelva a proponer el matrimonio y ella le conteste que se lo pensará. Frente al orden social vigente, se muestra el nacimiento de nuevas ideas en plena guerra civil. Cuando muere su marido, Julio, a causa de la caída de un obús en el bazar donde trabaja, Manolita se convierte en una mujer viuda con un niño pequeño. La vida continúa y ella intenta sobrevivir. María, la criada, le lleva botes de Maizena para el niño, ya que viven circunstancias muy complicadas durante la contienda. Con el desarrollo de la acción dramática, se agrava la situación de la familia de don Luis y los pocos víveres que quedan están controlados por las fuerzas militares. Sólo hay escasas lentejas que no cubren la necesidad de la gente. Al preparar la comida con las lentejas, doña Dolores las prueba con una cucharada de café. Al descubrir que faltan dos o tres cucharas de cada plato, Manolita confiesa que antes de comer ha ido a la cocina de vez en cuando para comer algo, y no creía que se notase. Argumentando este hecho dice: "No lo hago por mí, os lo juro, no lo hago por mí, lo hago por ese hijo. Tú lo sabes, mamá, estoy seca, estoy seca..."21. La madre la abraza con ternura y la reacción del resto de los miembros de su familia es positiva. A pesar de las divergencias ideológicas de los personajes, el autor sustituye la violencia, que cubre gran parte del arte teatral español durante la guerra, por el dialogo y el entendimiento mutuo, por el amor que subyace en el ambiente en que se mueven los miembros de esta familia. Así, Fernán Gómez transmite, con gran y minucioso detalle, la vida cotidiana de la sociedad española, sin expresar ira ni rabia. Por eso, la obra no es una gran tragedia, y no lo es, porque a pesar de las frustraciones, muertes, miedos y confrontaciones, surgen excelentes amistades, proyectos y ganas de vivir.

Otro caso de matrimonio es el de Basilio con María, la criada. Éste era partidario de la República. En el aspecto económico, aparece como valedor de la situación, pero es un verdadero oportunista. También es el superviviente de unas circunstancias muy conflictivas, pero pudo ganarse a la gente y consiguió un empleo importante dentro del sector de alimentación. Él se casó con María durante la guerra. En el cuadro XV de esta pieza, ella aparece de nuevo visitando a los amos de la casa y les comunica que Basilio ya no es su pareja. 
Doña Marcela interviene justificando esta separación, diciendo: "Ni valen los divorcios ni valen los matrimonios"22. Basilio no quería formalizar la situación con una boda precipitada, y María considera su actitud como una 'charranada'. Se casaron partiendo de un concepto nuevo de matrimonio, como el de Manolita con el miliciano, de mutuo acuerdo entre la pareja. Sin embargo, cuando termina la guerra y los nacionales quedan vencedores, vuelven a las antiguas leyes vigentes. Los deseos, los anhelos y las esperanzas que Anselmo prometió al comienzo de la segunda parte de esta pieza, se convirtieron en un espejismo. Las nuevas aspiraciones adoptadas durante la Segunda República no valdrán ya cuando termine la Guerra Civil, en 1939.

Desde el punto de vista religioso, el divorcio disuelve y descompone la unión que crea el matrimonio, una unión que solo termina cuando muere uno de los cónyuges. Puesto que se trata de una institución sagrada, la población no debía tomar a la ligera la idea de disolverla. De todas formas, la idea del divorcio es castigada e intolerable para la época, sin bases fundamentadas bíblicamente en la religión católica. Por eso, los mandatos y las ordenanzas religiosas generarán una visión determinista, que a su vez delimita y a veces ata la libertad de la mujer y también la del hombre. La situación de los divorcios en España, antes del inicio de la República en 1931, se regía por las leyes vigentes y casi era imposible el derecho al divorcio en épocas anteriores. Fernán Gómez capta la nueva idea de divorcio personificada y encarnada en doña Marcela, esposa de don Simón. Ésta es partidaria de la libertad, del libre pensamiento y del progreso, y su diálogo es chispeante y vivo. Su ideología y su personalidad se ponen de manifiesto cuando habla de su marido, que tiene más ganas de perderle de vista que ella a él. En el acto III, aparece con su familia en casa de doña Antonia, donde se observa el desacuerdo mutuo que predomina en la conversación con don Simón, delante de todos los demás visitantes. Cuando hablan del asesinato de Calvo Sotelo, ella argumenta que hechos o acontecimientos de este tipo no pueden ser justificados por motivos como la libertad, el progreso y la revolución. Don Simón contraataca intentando darle la impresión de que no ha defendido este asesinato y que él lamenta lo sucedido. En el segundo segmento del III acto, empiezan las intervenciones de los dos ancianos, doña Marcela y don Simón, cargadas de enfrentamiento y tensión.

Doña Marcela: (Encarándose con su marido) - ¿Lo oyes, Simón? Estas cosas no hay nada que las justifique: ni la revolución, ni el progreso, ni la lucha por la libertad, ni nada.

Don Simón: -Yo no he dicho eso.

Doña Marcela: -Si lo has dicho. A mí. Hace un rato.

Don Simón: -Lo que pasa es que no me comprendes cuando hablo.

Doña Marcela: -Será porque no te expresas. Pero te pongas como te pongas, esta ha sido una salvajada. 
Don Simón: -Cállate, Marcela, que tú no entiendes de es ${ }^{23}$.

Poco más tarde, llega la acción dramática de este segmento a su punto culminante y con la intervención de don Ambrosio, su hijo y su esposa Laura se alivia y baja la carga dramática de la situación. Pero, don Simón vuelve de nuevo al ataque mandando callar a doña Marcela. Los choques seguidos en el dialogo entre ambos personajes son como una especie de introducción del desarrollo de la acción dramática, que tendrá sus resultados en la segunda parte, puesto que el tema del divorcio predomina en las intervenciones de doña Marcela con sus amigas, doña Dolores y doña Antonia. La acción dramática del cuadro $\mathrm{X}$ tiene lugar en el mismo espacio: el comedor de doña Antonia, donde se ven sentadas doña Marcela, doña Dolores y doña Antonia. Mientras suenan disparos sueltos, seguidos de la corta ráfaga de una ametralladora, los tres personajes mantienen un diálogo dinámico y vivo. De repente, la primera anuncia, con alegría, la noticia de su divorcio de don Simón. Cuando le pregunta doña Dolores por qué ha tomado esta decisión a avanzada edad, contesta que se habría separado mucho antes, pero no existía el divorcio. Quiso pedirlo al llegar la República y no deseaba comunicarlo a nadie por su hijo, que era candidato a director de una sucursal bancaria en Teruel, y no quería dar 'la campanada'. Ante la sorpresa de sus amigas, de la tercera edad como ella, por la noticia del divorcio, se defiende resaltando sus argumentos ocultos:

Doña Marcela: -Y, ¿a qué alturas quiere usted que lo hubiera hecho, si antes no habia divorcio? Miren ustedes, en cuanto lo implantaron, pensé pedirlo... y ya me dirán lo que hubieran hecho ustedes casadas con ese cafre... Pero no lo hice, por mi hijo... Estaban a punto de nombrarle director del banco. Pero ahora, en esta situación, que cada uno hace lo que le sale de las narices... ${ }^{24}$

El marido de doña Marcela se caracteriza por sus breves frases e intervenciones, en las que expresa su desacuerdo con ella, no sólo en la incompatibilidad de caracteres, sino también en sus ideologías. Él escapa siempre de los círculos y reuniones familiares porque a veces debe ausentarse para ir a la casa del pueblo. Su mujer se opone, aduciendo que su ausencia la pasará descuidada y desatendida. Cuando le manda callarse, no parece que le causen ningún efecto las palabras de don Simón. En el último cuadro se traslada la escena al comedor de doña Dolores, donde aparece doña Marcela con las huellas de la guerra reflejadas en su rostro. Sus amigas intervienen ansiosas por saber lo que pasó en el proceso de divorcio, durante un año, y ella replica que han seguido viviendo en el mismo sitio, pero separados. Además, estaban tanto ella como su marido esperando que finalizase esta situación irregular, y a que él buscase una pensión, puesto que le tenía echado el ojo a una de la plaza de Santa Ana, que siempre le gustó mucho. Terminada esta unidad de acción, doña Marcela confiesa que en estos momentos la situación 
ha cambiado, tal y como lo redacta el dramaturgo: "No vale ningún divorcio de éstos de la zona roja. Ni los divorcios ni los matrimonios..."25. Se lamenta de que, con la nueva legislación, los divorcios no tengan efecto legal, por ello pierde totalmente la esperanza de conseguir su objetivo durante más cuarenta y ocho años. Acabada la guerra, todos los sueños de libertad, fraternidad e igualdad quedaron en el olvido y las nuevas leyes del sistema político republicano fueron invalidadas y arrasadas por los vencedores de la guerra. Los personajes se resignaron ante las normativas y cambios de estilo de vida del Régimen de la dictadura de Franco. Al fin y al cabo, doña Marcela, a pesar de su avanzada edad, siguió adelante y se rindió ante las circunstancias. La adaptabilidad al medio, por muy penoso que éste sea, es una cualidad de la condición humana, la supervivencia por encima de todo, en cada momento histórico.

\section{Fraternidad y amor libre}

El concepto del amor libre fue desarrollado por el feminismo de fines del siglo XIX y comienzos del siglo XX. Con el paso del tiempo y precisamente a mediados del siglo pasado, el concepto del amor libre se asoció fundamentalmente a los hippies de los años 60 en Estados Unidos. Estas ideas fueron integradas y experimentadas por el movimiento feminista en la década de los sesenta. Entre 1960 y 1970 se convierte el término 'amor libre' en una frase subrayada por amplios movimientos sociales y contraculturales. También influyeron sobre este tema del amor libre las obras literarias y los escritos de autores que defendían las relaciones amorosas y sexuales abiertas, entre las parejas o amigos, fuera del matrimonio. La libertad en la elección de la pareja, la práctica del sexo antes del matrimonio o sin necesidad de este contrato, y los avances en los derechos de las mujeres en general, sobre todo en el Reino Unido y Francia, fueron de gran influencia para el resto del continente europeo. La prohibición en España de la libertad sexual durante la época franquista, que en los países vecinos era latente, fue aceptada por determinadas capas sociales que defendían estas restricciones respecto a la conducta de las parejas.

Estos conceptos se reflejan en la obra de distintos modos. En la familia de don Luis y doña Dolores, Manolita, la hija, entabla una relación amorosa con el miliciano, como hemos mencionado en el apartado anterior. Pedro, hijo de doña Antonia, se enamora de una prostituta y se la lleva a casa para vivir juntos. Florentina, la criada de Pablo, amigo de Luís, recibe a un extranjero de las brigadas internacionales en casa de los amos. Las intervenciones y los monólogos de Anselmo en el cuadro IX tratan, a modo de introducción, la representación y caracterización de cada personaje a lo largo del desarrollo de la acción dramática. Las relaciones de este tipo aparecen en la pieza clandestinamente al principio, como el caso de Manolita, que confiesa se ante su madre, pasados los primeros cuatro meses de su embarazo. La madre no puede soportar y contener el escándalo y la infamia que trae la hija a la familia, 


\section{Dr. Abdel Hamid Aly Aly Ghalab}

según su modo de pensar. Doña Dolores se encuentra arrinconada e incapaz de encontrar una solución o una salida. La pobre replica: “¡Dios mío, Dios mío! ¿Y cuánto... cuánto tiempo llevas? (...) ¡Madre mía! No se puede hacer nada..."26. Frente al miedo que impulsa a su madre, Manolita enuncia la noticia con firmeza que no se siente culpable de este acto, además, utiliza argumentos negativos para justificar el hecho del embarazo y la relación inaceptable desde el punto de vista de la madre. Puesto que, aclara: "Mamá, no creo que, desde que empezó la guerra, sea la única mujer que ha tenido un hijo"27. Ambos personajes encarnan dos mentalidades contradictorias y opuestas. La madre pertenece a la generación clásica y tradicional, que cree en las relaciones de matrimonio tal y como suceden en la sociedad de aquella época, la generación de los abuelos. La hija representa el cambio de mentalidades y corresponde a otra generación, con lo cual, piensa de otra manera y cree en el amor libremente correspondido sin ataduras y sin normativas impuestas por tradición. Se guía por su deseo y sus sentimientos. Y ello entra en lucha con las antiguas creencias y convencionalismos.

Poco más tarde, aparece doña Antonia en el último segmento de este cuadro agobiada y nerviosa. Su diálogo con doña Dolores sintetiza la relación de su hijo Pedro con Rosa, que vive con éste bajo el mismo techo. Por medio de la carta de un anónimo, se entera la madre que esta chica "Es... es una mujer de la calle..." 28 y piensa que debe haber entre este tipo de mujeres muchas malquerencias. Desahogándose con doña Dolores, sube la energía dramática, ya que la pobre tiene un nudo en la garganta, desfallece y no puede tragar ni un poco de vino. Sigue entre ahogos contando que, a pesar de todo esto, Pedro está enamorado de Rosa y no quiere que ésta se marche de casa, y dice que ella también le quiere. Pero las réplicas de su vecina disminuyen la tensión y el sufrimiento psíquico de la madre de Pedro.

¿No dice usted ahora que los dos se quieren, y que ella se ha encariñado con usted? Pues, ;hala, a vivir...! De ahora en adelante el amor es libre, doña Antonia. ;Lo que nos hemos perdido usted y yo! ${ }^{29}$.

Se observa que la resistencia negativa de doña Antonia ante la rendición de doña Dolores nos introducen en un equilibrio de suma importancia. Puesto que doña Dolores concibe, a través de la relación de Manolita con el miliciano, que el universo creado por la sociedad clásica y tradicional ya no existe. Y que la generación de jóvenes puede invalidar este universo mediante el ejercicio de la libertad, aunque no se eliminan las contradicciones ni las tensiones dialécticas consustanciales a la realidad humana, sino que se asumen y se toleran por más que no las compartan.

Queda en el terreno afectivo la última relación amorosa entre dos personajes invisibles: Florentina y el hombre de las brigadas internacionales. Ésta es la criada de la casa de Pablo, amigo y vecino de Luís, que vive con su 
hermana y la criada en otro piso del mismo edificio. Se plantea esta relación en el cuadro VIII. La acción dramática de esta escena tiene lugar en cuarto de Luís, que está ocupado ordenando su biblioteca y, de vez en cuando, suspende su labor para atender con más interés a la conversación con Pablo. El diálogo empieza con un nivel bajo de energía como es propio del inicio de un segmento. Los dos adolescentes hablan sobre las restricciones impuestas por el gobierno y la evacuación de Madrid por motivo del enfrentamiento bélico. De esta manera, el espectador o lector se entera de lo que ocurre fuera del espacio escénico, del mundo en el cual viven los personajes y también de la Historia reciente de España.

Poco más tarde, cambian de tema y comienzan a hablar de sus preocupaciones y de sus vidas. El joven Luís, al igual que su padre, don Luis, es partidario de promover la libertad en la pareja y el dar rienda suelta a los sentimientos y los deseos afectivos. Realmente cree que el amor debe ser libre. Pablo, sorprendido ante los argumentos que su amigo, se reafirma y opina que cada hombre tiene que buscar a una mujer a la que quiera. Éste lo ve muy difícil y con el desarrollo de la progresión de la acción, anuncia la relación de Florentina con el chico de las brigadas internacionales. Justificando este hecho porque ella "ya no sabía qué hacer para encontrar comida... Como nos hemos quedado sin casi nada de dinero..." ${ }^{30}$. Luís empieza a intensificar sus preguntas sobre el motivo principal de esta relación de Florentina, que, por lo visto, recibe a su amigo en el dormitorio de los padres de su vecino. La tensión y energía dramáticas suben y con cierta rabia contenida, Pablo le comunica que ello sucede "porque le gusta el de las brigadas" 31 . Luís sigue apretando a Pablo con diversas preguntas sobre los comportamientos de la criada y su amigo, dentro de su propia casa y el tipo de comida que trae. Poco a poco, Pablo entra en tensión con los nervios a flor de piel y rompe a llorar, llegando la escena a su punto culminante. Se observa, en los discursos de los dos personajes al igual que algunos testimonios, cual es la visión del amor de pareja y las libertades adquiridas en aquella época. Estas controversias sociales, en la modernidad de la moral y la ética de las relaciones afectivas, dan ejemplos de las libertades perdidas en esta sociedad occidental durante los años de la Guerra Civil española. Fernán Gómez ha captado unas ideologías diversas que suceden en espacios cerrados, cercanos a todos y domésticos; y los representa en moldes significativos mediante personajes de diferentes edades. Pablo y Luís son dos adolescentes, Manolita y Juan son jóvenes, Basilio y María son mayores. Todos estos personajes reunidos tienen un punto de unión en común: las diatribas y las confrontaciones generacionales y de clase, nacidas en pleno enfrentamiento bélico.

En un artículo realizado por el profesor Miguel Medina Vicario sobre la dramaturgia de Fernando Fernán Gómez donde relaciona Las bicicletas son para el verano y El viaje a ninguna parte con El lazarillo de Tormes, lo analiza 


\section{Dr. Abdel Hamid Aly Aly Ghalab}

como un dramaturgo que da cuerpo a los diferentes personajes que conformaron una historia. Y en todos ellos, "el autor sintetiza los rasgos básicos con una economía esclarecedora. (...) El Lázaro de Fernán Gómez, como los cómicos de El viaje a ninguna parte, como los personajes de Las bicicletas son para el verano, son un juguete hambriento en manos de un tropel humano" 32 . Terminando este apunte, el autor de la obra que estudiamos nos presenta todas estas actitudes frente a la vida, mediante personajes atrapados en un universo creado por las circunstancias del enfrentamiento entre hermanos, vecinos y allegados, la Guerra Civil, que cuando tocó su fin, todos fracasaron en conseguir sus objetivos y hacer válidas sus esperanzas de paz. Como dice don Luís: "No ha llegado la paz, ha llegado la victoria". Sus diálogos e intervenciones han sido un gran testimonio valiosísimo de los detalles de la vida cotidiana. Este autor pudo expresar con precisión, valentía y economía dramáticas las tensiones enmascaradas en momentos muy críticos para los españoles en los años treinta del siglo pasado. Sobre todo, confirmando que en el terreno de las relaciones de pareja y los nuevos matrimonios hubo un agujero legal, ético y de tradiciones, ahondando en un retroceso en la vivencia de sexualidad de los jóvenes. Siendo, así, de nuevo reprimida la vida sexual de las parejas y vista como éticamente reprobable antes del matrimonio, según los postulados de la dictadura franquista hasta que llega la transición democrática. Todo esto tardó en cambiar hasta a mediados de los años setenta con la entrada de las nuevas ideas que llegaron desde otros países europeos más progresistas, como Inglaterra, Francia y Holanda, entre otros países occidentales, o bien países norteamericanos como Canadá y Estados Unidos. El mundo cambia y el teatro actual es un fiel reflejo de las distintas sociedades y las diferentes culturas que pueblan el planeta. Finalmente, la moraleja que aporta Las bicicletas son para el verano es una lección de lo que fue el pasado de un país, de lo que es el presente de otras guerras, y de lo que no ha de representar el futuro. ¡No a la guerra!

\section{Conclusiones}

Las bicicletas son para el verano expone el compromiso que adopta el dramaturgo con los problemas de la humanidad en un momento determinado de la Historia, con una actitud crítica respecto a las tendencias sociales en las que se desarrolla el conflicto vital de los seres humanos. Se trata de una pieza en la que los personajes que perdieron la guerra cargan sobre sus espaldas cansadas la resignación y la sumisión huyendo de un castigo mayor. Su autor destaca, mediante un gran sentido humanitario, que los límites entre vencedores y vencidos se desvanecen para conceder un halo de esperanza a uno de los momentos más trágicos en la historia de España. 
Durante los conflictos establecidos entre los personajes en plena Guerra Civil, fuera de la vista del espectador, Fernán Gómez pone, en boca de éstos, soluciones para los problemas y sus tragedias personales. La guerra en sí supone, en esta obra, un motivo secundario, ya que lo que se teatraliza son sus efectos. Cada personaje posee una especial particularidad, y aporta las diversas caras de la dialéctica y el progreso durante la acción dramática. La obsesión por el cambio de vida, el avance en las libertades y derechos sociales, es el objetivo fundamental de los personajes corales o colectivos, sobretodo la familia de don Luís, representados como librepensadores.

Sus deseos de libertad están subrayados en los discursos y diálogos mantenidos entre la mayoría de los personajes. El sentido de las aspiraciones, anhelos y esperanzas, por parte de los vencidos, cubre gran parte del texto dramático, puesto que las intervenciones, desde el inicio hasta el final, llevan una carga dramática de alto nivel literario y artístico, sobre todo las intervenciones de Anselmo. A nivel pragmático, existen visiones paralelas en contextos muy diferentes, como el caso del embarazo de Manolita.

Cuando se descubre que todo ha cambiado y que la generación joven tiene sus nuevas tendencias y criterios, se manifiesta el conformismo y la sumisión por parte de la generación anterior, ante un nuevo contexto extremo. Y a pesar de las divergencias, las diferencias ideológicas y políticas de los personajes que dialogan, se ayudan y se desahogan unos con otros. También, los enfrentamientos ideológicos carecen de violencia a causa de sus simpatías, afectos y afinidades.

En lo relacionado con matrimonios y divorcios, en el apartado III, que es el segundo eje principal de nuestro trabajo, se resalta la diferencia generacional de pensamiento entre padres e hijos. Donde se sustituyen las divergencias personales por el entendimiento mutuo y por el amor que subyace en el ambiente en que se mueven los actores. A pesar de las frustraciones, muertes, miedos y confrontaciones, nacen excelentes amistades, proyectos y ganas de vivir. Por tanto, el carácter trágico de la obra se desvanece ante las cualidades anteriormente mencionadas.

Terminada la guerra, todos los sueños de libertad, fraternidad e igualdad quedaron en el olvido y las nuevas tendencias del sistema republicano fueron invalidadas y arrasadas por los vencedores. La sociedad española se resignó ante las normativas y cambios de estilo de vida del Régimen de la dictadura de Franco. Encarna esta situación doña Marcela que, a pesar de su avanzada edad, siguió adelante rindiéndose ante las circunstancias que impusieron otra verdad histórica.

Los jóvenes tuvieron que morderse la lengua, asumir y callar o bien se las verían con la justicia o con la crítica mordaz de una sociedad que acataba y se resignaba. El juego, la vivencia y la expresión de los afectos entre parejas, quedaron reprimidos y mal vistos. Tanto hombres como mujeres tuvieron que 


\section{Dr. Abdel Hamid Aly Aly Ghalab}

representar el papel costumbrista de lo que se entendía por honradez y buenos modales, y que el autor pone en cuestión emparejando casos extremos y confrontando distintas generaciones y clases sociales.

La guerra marcó a toda una generación que hoy en día está a punto de desaparecer por la edad, la ley de la vida. Los años transcurridos desde la época que esta obra teatral representa, hace más de ochenta años de estos hechos, han quedado atrás. España ahora es un país diferente, con las cicatrices de aquel drama, que intentan sanar restituyendo el honor de los vencidos y de sus muertos, a veces con cariño, otras, con la crítica, y, finalmente, a través del Arte, como en la obra literaria que analizamos en este trabajo. La experiencia ha supuesto una reflexión atemporal, aplicable a cualquier momento histórico en el cual lo nuevo deja atrás a lo viejo o caduco, discute y empuja los convencionalismos si estos no se adaptan a los medios de vida razonables en el momento de ser vividos. La supervivencia siempre ocupa un lugar predominante y la juventud es quien ha de gobernar el mundo del futuro. Por ello, y como conclusión, esta obra es el diálogo interior del autor entre dos polos opuestos o, mejor dicho, contrapuestos, entre lo nuevo y lo viejo, la imposición y la devoción, naturaleza y artificio, tradición y modernidad.

\section{Bibliografía}

Alonso de Santos, José Luis, La cena de los generales, Madrid, Clásicos Castalia, Edición, introducción y notas de Andrés Amorós.

Artaud, Antonin, El teatro y su doble, Barcelona, Edhasa, 1987.

Bejarano, Fernando, Brillante estreno de Las bicicletas son para el verano, Diario 16, 25 de abril de 1982 .

Berenguer, Ángel, Historia del teatro español del siglo XX (1975-1982), Madrid, Biblioteca nueva, 1998.

Fernán Gómez, Fernando, Las bicicletas son para el verano, Barcelona, Ediciones Vicens Vives, 1987, Edición de Manuel Aznar Soler, , Las bicicletas son para el verano, Madrid, Espasa Libros, 2011.

Gabriel, John, Conversaciones con Lauro Olmo, Madrid, Anales de la literatura española contemporánea, Núm. 16, 1999.

1962

García Pavón, Francisco, Teatro social en España (1895-1962), Madrid: Taurus,

Gutiérrez Carbajo, Francisco, Literatura española desde 1939 hasta la actualidad, Madrid, Editorial Universitaria- Ramón Areces, 2011.

Gutiérrez Palacios, Javier, Historia de la literatura española, siglo XX, Madrid, Ediciones Tiempo, , 1984.

Haro Tecglen, Eduardo, Una obra maestra, El país, 25 de abril de 1982.

Medina Vicario, Miguel, Veinticinco cinco años de teatro, Madrid, Editorial Fundamentos, 2003.

Ruiz Ramón, Francisco. Historia del teatro español desde sus orígenes hasta 1900, Madrid, Alianza Editorial, 1967. 


\section{Bibliografía}

${ }^{11}$ La posguerra llevó al teatro a una crisis general por la censura y la pobreza. Se ha roto el ambiente renovador de Lorca en los tiempos de la Republica. También el miedo a introducir novedades y las prohibiciones han sido motivo de aquella crisis. El panorama teatral de la posguerra se puede clasificar en dos tendencias: El teatro de humor y la alta comedia benaventina. Ambos presentan un teatro sin propósitos sociales y sin arriesgar en ningún sentido. Sus representantes son Enrique Jardiel Poncela, Joaquín Calvo Sotelo, José López Rubio, Miguel Mihura, etc. En la década de los años cincuenta surge el teatro comprometido liderado por Antonio Buero Vallejo con las resonancias sociales de Historia de una escalera (1949) y Alfonso Sastre con el estreno de Escuadra hacia la muerte (1953), donde la realidad social vuelve al escenario. Ambos autores tenían un compromiso tanto estético como ético, en tiempos de censura y falta de expresión. El teatro comprometido de Sastre y Buero inspiró a la Generación realista, en los años setenta, a escribir obras de denuncia y protesta ante la injusticia social, la marginación, las desigualdades y la hipocresía. Entre los autores de esta tendencia destacan Lauro Olmo con el estreno de La camisa, en 1962, y José Martín Recuerda con la puesta en escena de Las salvajes en Puente San Gil, en 1963. También en los años setenta hubo otra novedosa línea principal y argumental, el teatro del absurdo. Una corriente de teatro europeo que rompe totalmente con el teatro convencional, lo llaman antiteatro, sus diálogos y segmentos están llenos de sorpresas y provocaciones, y, aparentemente, no transmiten ni ideas ni sentimientos. Los mensajes de este tipo de teatro son ilógicos y, como su nombre indica, absurdos. Los precursores en Europa son Ionesco y Beckett. Fernando Arrabal es el autor español más conocido en España como representante de este género teatral con su famosa obra Pic Nic, estrenada en 1957. En el último cuarto del siglo pasado surge el teatro independiente (época de democracia y del fallecimiento de Franco), caracterizado por la autoría colectiva y la experimentación, representado por grupos de aficionados. Paralelamente, nace el teatro del autor con más éxito teatral y comercial. La representación cuenta con un texto literario de un autor. Dentro del repertorio del teatro de autor destacan: Fermín Cabal, que estrena Esta noche gran velada, en 1983; Fernando Fernán Gómez, que estrena Las bicicletas son para el verano, en 1982, objetivo de nuestro trabajo. Antonio Gala pone en escena Anillos para una dama, en 1973. José Luis Alonso de Santos estrena, en 1985, Bajarse al moro; José Sanchís Sinisterra estrena, en 1986, Ay, Carmela.

2 Fernán Gómez, Fernando, Las bicicletas son para el verano, Barcelona, Clásicos Hispánicos, Editorial Vicens Vives, 2002, edición de Manuel Aznar Soler y José Ramón López García, pág. 26.

${ }^{3}$ La previsión era representarla en El Teatro Español de Madrid durante dos meses y a causa de una huelga del personal técnico del teatro, el estreno se retrasó un mes más. Ello provocó que, tras su triunfal acogida, una obra en pleno éxito, llenando a diario el aforo y con el aplauso incondicional de la crítica, únicamente pudiera representarse durante treinta funciones. Ante las protestas, se decidió programarla al inicio de la nueva temporada, pero "una inoportuna caída" de Agustín González retrasó la fecha de la reposición, que tuvo lugar el 2 de noviembre de 1982. Casi inmediatamente comenzó la historia de las largas colas frente a la taquilla, de los llenos absolutos, incluso, de la reventa ilegal y alteraciones del orden público. Véase Primer Acto, octubre, 1982, pág. 21.

${ }^{4}$ Haro Tecglen, Eduardo, "Una obra maestra”, El país, 25 de abril de 1982, pág. 37.

5 Bejarano, Fernando, "Brillante estreno de Las bicicletas son para el verano”, Diario 16, 25 de abril de 1982, pág. 33.

${ }^{6}$ Gutiérrez Palacios, Javier, Historia de la literatura española, siglo XX, Madrid, Ediciones Tiempo, 1884, pág. 1025. 


\section{Dr. Abdel Hamid Aly Aly Ghalab}

${ }^{7}$ La obra se desarrolla en el exterior de un edificio de apartamentos. Varias vidas transcurren, simples o complejas, anónimas, dentro del bloque y fuera de él. Simplemente, la principal protagonista es la calle.

${ }^{8}$ Gutiérrez Carbajo, Francisco, Literatura española desde 1939 hasta la actualidad, Madrid, Editorial Universitaria-Ramón Areces, 2011, pág. 231.

${ }^{9}$ Berenguer, Ángel, Historia del teatro español del siglo XX (1975-1982), Madrid, Biblioteca nueva, 1998, pág. 128.

${ }^{10}$ Véase García Pavón, Francisco, Teatro social en España (1895-1962), Madrid, Taurus, 1962. Y Ruiz Ramón, Francisco. Historia del teatro español desde sus orígenes hasta 1900, Madrid, Alianza Editorial, 1967.

${ }^{11}$ Fernán Gómez, Fernando, Las bicicletas son para el verano, Madrid, Espasa libros, 2011, págs. 150-151. A lo largo de la elaboración de este trabajo seguiremos esta edición.

${ }^{12}$ Ibíd., pág. 156.

${ }^{13}$ Alonso de Santos, José Luis, La cena de los generales, Madrid, Clásicos Castalia, Edición, introducción y notas de Andrés Amorós, pág. 155.

14 Las bicicletas son para el verano, op. cit, pág. 167.

${ }^{15}$ Ibídem, pág. 167.

${ }^{16}$ Ibid, pág. 151.

${ }^{17}$ Artaud, Antonin, El teatro y su doble, Barcelona, Edhasa, 1987, pág. 88.

${ }^{18}$ Las bicicletas son para el verano, op, cit, pág. 222.

${ }^{19}$ Ibid. pág. 164.

${ }^{21}$ Gabriel, John, “Conversaciones con Lauro Olmo", Anales de la literatura española contemporánea, Núm. 16, 1999, pág. 385.

${ }^{21}$ Las bicicletas son para el verano, op. cit, pág. 188.

22 Ibid, pág. 205.

${ }^{23} \mathrm{Ibid}$, pág. 84.

${ }^{24}$ Ibíd, pág. 162.

${ }^{25}$ Ibid, pág. 200.

${ }^{26}$ Ibid, pág. 163 .

${ }^{27}$ Ibid, pág. 165.

${ }^{28}$ Ibid, pág. 166.

${ }^{29}$ Ibid, pág. 167.

30 Ibid, pág. 144.

31 Ibid, pág. 145.

${ }^{32}$ Medina Vicario, Miguel, Veinticinco años de teatro, Madrid, Editorial Fundamentos, 2003, pág. 146. 